\title{
Coleoptera associated with macrophytes of the genus Salvinia in four oxbow lakes in two river basins in southeast Brazil
}

\author{
M. C. Paula-Bueno ${ }^{a *}$ and A. A. Fonseca-Gessner ${ }^{b}$ \\ aPrograma de Pós-Graduação em Ecologia e Recursos Naturais, Universidade Federal de São Carlos - UFSCar, \\ Rod. Washington Luiz, Km 235, CP 676, CEP 13565-905, São Carlos, SP, Brazil

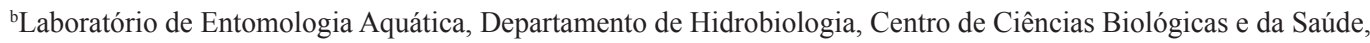 \\ Universidade Federal de São Carlos - UFSCar, CP 676, CEP 13565-905, São Carlos, SP, Brazil \\ *e-mail: marciacdp@ig.com.br
}

Received: April 25, 2014 - Accepted: September 7, 2014 - Distributed: November 30, 2015

(With 4 figures)

\begin{abstract}
Macrophytes in oxbow lakes represent an important substrate for the Coleoptera. Two oxbow lakes the Rio Paranapanema were studied and the other two Rio Mogi-Guaçu, in the State de São Paulo, Brasil. In this study, there is greater similarity between the communities of Coleoptera of lakes greater connectivity with the main river channel or the difference in the species of Salvinia collected in the lakes studied interferes Coleoptera fauna that uses as substrate. A total of 9,222 specimens of Coleoptera were collected and identified in 10 families and 40 genera. The analysis MDS for abundance of Coleoptera showed the grouping of the oxbow lakes the Paranapanema River and a distancing the oxbow lakes the Mogi-Guaçu. The PERMANOVA test did not reveal any difference in the fauna between the wet and dry periods. It was concluded that the connectivity between river and lake is not decisive for the richness and abundance of aquatic fauna of Coleoptera. Therefore, the richness and abundance of aquatic Coleoptera associated vary with the species of Salvinia used as substrate.
\end{abstract}

Keywords: aquatic macrophytes, oxbow lakes, aquatic insects, phytofauna.

\section{Coleoptera associados à Salvinia em quatro lagoas marginais pertencentes a duas bacias hidrográficas no estado de São Paulo, Brasil}

\section{Resumo}

As macrófitas em lagoas marginais constituem um importante substrato para os Coleoptera. Foram estudadas duas lagoas marginais ao Rio Paranapanema e outras duas ao Rio Mogi-Guaçu, no estado de São Paulo, Brasil. Neste estudo, haverá maior similaridade entre as comunidades de Coleoptera das lagoas de maior conectividade com o canal princial do rio ou a diferença na espécie de Salvinia coletada nas lagoas estudadas interfere na fauna de Coleoptera que a utiliza como substrato. Foram coligidos 9.222 espécimes de Coleoptera sendo identificadas 10 famílias e 40 gêneros. A análise MDS para abundância de Coleoptera mostrou o agrupamento das lagoas marginais ao Rio Paranapanema e um distanciamento das lagoas marginais ao Rio Mogi-Guaçu. Os resultados da análise PERMANOVA não mostraram diferença na composição faunística entre os períodos de chuva e seca. Concluiu-se que a conectividade entre rio e lagoa não é determinante para a riqueza e abundância da fauna de Coleoptera aquáticos. Portanto, a riqueza e a abundância de Coleoptera aquáticos associados variam com as espécies de Salvinia utilizadas como substrato.

Palavras-chave: macrófitas aquáticas, lagoas marginais, insetos aquáticos, fitofauna.

\section{Introduction}

Floodplains are formed by stretches of river flowing across gently sloping land, where the adjacent areas are flat. The temporary or permanent nature of these flooded areas is determined by the geomorphology of the area and the pattern of fluctuation of the water level (Henry, 2003).

Oxbow lakes, water bodies typical of floodplains, differ in morphometry and physiognomy, depending on how far they are from the main river of the system

(Santos and Mozeto, 1992). In general, the littoral region of these lakes is colonized by a mix of water macrophyte (Glowacka et al., 1976). One of the distinguishing features of the oxbows in the floodplains of the Paranapanema and Mogi-Guaçu Rivers is the abundance of these plants, especially the extended stands of macrophytes of the genus Salvinia. These may be used as a food source (Thomaz and Cunha, 2010), site for oviposition of insects (Merritt and 
Cummins, 1996), refuge from predators (Scheffer, 1998) and which represent an important substrate for benthic macroinvertebrates (Glowacka et al., 1976).

Among the insects found in freshwater systems, the Coleoptera form a group of great diversity and abundance (Fairchild et al., 2000), with about 10,000 species that are aquatic at one or more stages of development (Jäch and Balke, 2008). Some genera of the suborders Adephaga and Polyphaga are common inhabitants of lentic habitats, especially associated with plants in lakes, or in the sediment of shallow temporary ponds (Benetti and Cueto, 2004; Jäch and Balke, 2008).

Although the number of studies on aquatic Coleoptera in Brazil has been growing in the last few years, mainly in the work of Dr Nelson Ferreira-Junior (Ferreira-Junior et al., 1998, 2006; Ferreira-Junior and Braga, 2009), in the state of Rio de Janeiro, and Dr César João Benetti (Benetti et al., 2003, 2006; Benetti and Cueto, 2004), in the state of Rio Grande do Sul, they are still rare. Thus, this study is a pioneering investigation of the diversity and abundance of coleopterans associated with stands of Salvinia in four oxbow lakes in São Paulo State, two being in the drainage basin of the Paranapanema River and two in that of Mogi-Guaçu River.

\section{Material and Methods}

\subsection{Study area}

The climatic conditions in the river basins under study are classified as Köppen Aw (Setzer, 1966), with two periods: a hotter rainy season from November to April and a drier, more temperate season from May to October (Cavalheiro et al., 1990).

Lake Diogo and Lake Óleo (Figure 1), oxbow lakes left after meanders of the Mogi-Guaçu River, are located within the Jataí Ecological Station, a Conservation Unit in the district of Luis Antônio (São Paulo State, Brazil), between latitudes $21^{\circ} 33^{\prime}$ and $21^{\circ} 37^{\prime} \mathrm{S}$ and longitudes $47^{\circ} 45^{\prime}$ and $47^{\circ} 51^{\prime} \mathrm{W}$.

Lake Cavalos and Lake Coqueiral (Figure 2), oxbow lakes in the Paranapanema River basin, are located near the point where the river flows into the Jurumirim Reservoir, in the district of Angatuba (São Paulo State, Brazil), between latitudes $23^{\circ} 08^{\prime}$ and $23^{\circ} 35^{\prime} \mathrm{S}$ and longitudes $48^{\circ} 30^{\prime}$ and $49^{\circ} 13^{\prime} \mathrm{W}$.

\subsection{Fauna collection and analysis}

Three sampling sites were chosen in the littoral region of each lake, in places where stands of Salvinia were present, were collected at monthly intervals for one year, between March 2006 and February 2007 in the Paranapanema River lakes and between March 2010 and February 2011 in the Mogi-Guaçu Lakes. In the Lake Diogo, Coqueiral and Cavalos was collected Salvinia auriculata, in the Lake Óleo was collected Salvinia molesta. The plants were sampled with a small circular shrimp net of area $0.07 \mathrm{~m}^{2}$ and mesh $0.25 \mathrm{~mm}$ and transported in the lake water in plastic pots to the laboratory. There, the fauna was extracted from the plant material by the method described by Afonso (2002). Coleopterans were preserved with $70 \%$ ethanol in bottles and identified under a stereo microscope, with the aid of taxonomic keys (Archangelsky et al., 2009;

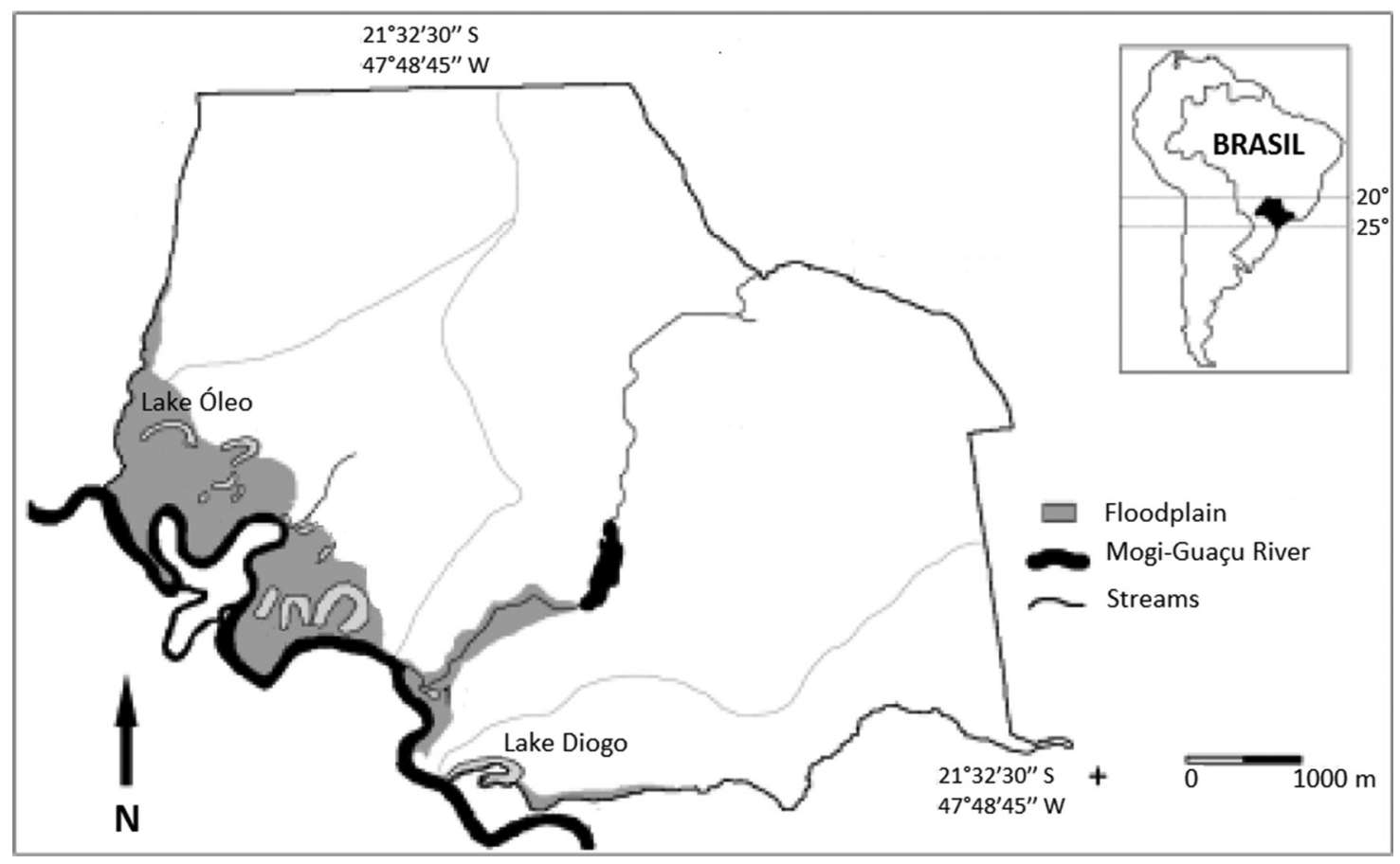

Figure 1. Location of Jataí Ecological Station with oxbow lakes in the floodplain, Lake Diogo and Lake Óleo (Adapted from: Marçal-Simabuku and Peret, 2002). 


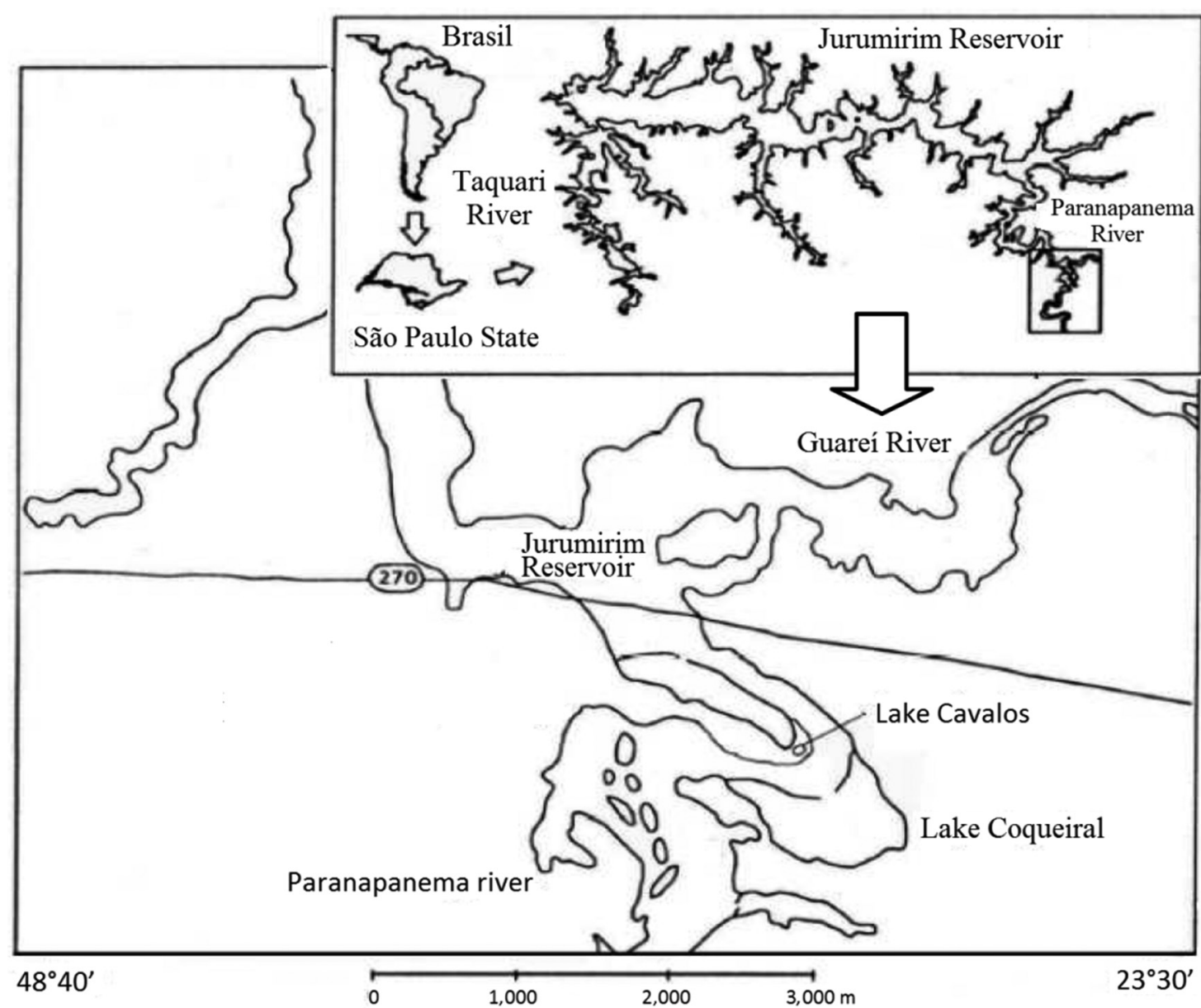

Figure 2. Paranapanema River in the region of its mouth in Jurumirim Reservoir, with oxbow lakes, Lake Coqueiral and Lake Cavalos (Adapted from: Davanso \& Henry, 2006).

Benetti et al., 2003; Epler, 1996), specialized literature and expert assistance where necessary.

In order to analyze the composition of the aquatic coleopterans, the following metrics were calculated: taxon richness observed (sum of collected taxons) (S), total abundance $(\mathrm{N})$, Shannon's diversity index (H'), Pielou's evenness index (E) and Simpson's dominance index (D).

To verify the similarity of the fauna in the four lakes studied, multidimensional scaling (MDS) analysis was performed with the program Past 2.09 (Hammer et al., 2001), on the basis of Bray-Curtis dissimilarity. The abundance data were subjected to the $\log (\mathrm{x}+1)$ transformation, so as to diminish the influence of taxa present in very large numbers. Subsequently, a SIMPER analysis was used to identify those taxa that contributed the most to the dissimilarities between the lakes.

Differences in fauna composition between the lakes and between rainy and dry periods were identified by means of a PERMANOVA (Anderson, 2001), utilizing 1,000 permutations, with Bray-Curtis as a measure of dissimilarity and $p<0.05$ as the criterion of significance. To obtain a graphic representation of the dissimilarity between the two climatic periods, an MDS analysis was carried out, employing the Bray-Curtis coefficient.

\section{Results}

From the analysis of the 9,222 collected specimens of coleopterans (beetle larvae and adults), 55 taxonomic units were identified as occurring in at least one of the lakes. These pertained to 10 families and 40 genera. Of these, 8 genera and 2 families were common to all 4 lakes. The family Hydrophilidae ("water scavenger beetles") predominated, representing almost $49 \%$ of all collected specimens, and the genus Helochares was numerically outstanding within this family, at both the larval and adult stages. The families Scirtidae and Noteridae ("burrowing water beetles") also made significant contributions to the community, with $24.3 \%$ and $15 \%$ of the specimens, respectively.

The numerical totals of specimens, families and genera were extremely similar in the 2 river basins: $51.4 \%$ of the specimens were collected from Lakes Diogo and Óleo, of the Mogi-Guaçu River basin, and these specimens were spread over 9 families and 26 genera (Tables 1 and 2), while the remaining $48.6 \%$ were from Lakes Coqueiral and 
Table 1. Abundance of Coleoptera coletados in Lake Diogo for each month from March 2010 to February 2011.

\begin{tabular}{|c|c|c|c|c|c|c|c|c|c|c|c|c|}
\hline & \multicolumn{12}{|c|}{ Lake Diogo } \\
\hline & Mar & Apr & May & Jun & Jul & Aug & Sep & Oct & Nov & Dec & Jan & Feb \\
\hline \multicolumn{13}{|l|}{ Curculionidae } \\
\hline $\begin{array}{l}\text { Cyrtobagous singularis Hustache, } \\
1929 \text { A }\end{array}$ & 26 & 16 & 23 & 12 & 12 & 26 & 17 & 14 & 8 & 8 & 6 & 13 \\
\hline \multicolumn{13}{|l|}{ Neochetina eichorniae Warner, 1970 A } \\
\hline $\begin{array}{l}\text { Neobagous coarcticollis Hustache, } \\
1926 \text { A }\end{array}$ & & & & & & & & & & & 1 & \\
\hline Curculionidae L & 46 & 26 & 40 & 54 & 25 & 1 & & & & 1 & & 1 \\
\hline \multicolumn{13}{|l|}{ Dytiscidae } \\
\hline Derovatellus A & & & & & & & & & & 1 & & \\
\hline Laccophilus A & 1 & 1 & 3 & 3 & 3 & & 1 & 1 & & 1 & 1 & 1 \\
\hline Pachydrus A & & & & & & & & & & 1 & & \\
\hline Hydrovatus $\mathrm{L}$ & & 1 & & & & & & & & & & \\
\hline Laccophilus L & 3 & & & & & & 2 & 2 & 5 & 2 & 4 & 1 \\
\hline Morfotipo $1 \mathrm{~L}$ & 1 & & & & & & & & & 1 & & \\
\hline \multicolumn{13}{|l|}{ Elmidae } \\
\hline Macrelmis L & & & & & & & & & & 1 & & \\
\hline \multicolumn{13}{|l|}{ Hydrochidae } \\
\hline Hydrochus A & & & & & & 1 & 1 & & & & & \\
\hline \multicolumn{13}{|l|}{ Hydrophilidae } \\
\hline Anacaena A & & & & & & & & 1 & & & & \\
\hline Derallus A & 5 & 4 & 7 & 4 & 9 & 3 & 4 & 1 & & & & \\
\hline Helochares A & 35 & 37 & 45 & 28 & 26 & 39 & 16 & 10 & 4 & 10 & 7 & 5 \\
\hline Phaenonotum A & & 1 & 4 & 5 & 8 & 8 & 7 & & & & & \\
\hline Tropisternus A & 12 & 7 & 9 & 7 & 10 & 3 & 2 & 4 & & 1 & & \\
\hline Derallus L & 31 & 33 & 10 & 7 & 10 & 20 & 8 & 2 & & 7 & 3 & 3 \\
\hline Enochrus L & & & & & 1 & & 1 & 1 & & 1 & & 3 \\
\hline Helochares L & 63 & 80 & 85 & 35 & 104 & 84 & 82 & 32 & 43 & 36 & 37 & 55 \\
\hline Phaenonotum L & 1 & 1 & 1 & 1 & & & & 2 & 1 & 1 & 1 & \\
\hline Tropisternus L & 33 & 9 & 16 & 1 & 3 & 13 & 2 & 1 & & 6 & & 9 \\
\hline Lampyridae L & & & & & & & & & 1 & & & \\
\hline \multicolumn{13}{|l|}{ Noteridae } \\
\hline Hydrocanthus A & & 1 & 2 & 3 & 4 & 4 & 1 & 1 & & & & \\
\hline Suphis A & & & & & & & & 1 & & & & \\
\hline Suphisellus A & & & & 1 & & & & & & & & \\
\hline Hydrocanthus L & 2 & & & & & & & & 1 & & & \\
\hline Scirtidae L & 22 & 17 & 22 & 21 & 16 & 5 & 6 & 29 & 4 & 52 & 37 & 51 \\
\hline Staphylinidae & & & & & & & & & & & & \\
\hline $\begin{array}{l}\text { Paederus punctiger Sharp, } \\
1876 \text { (affinis) A }\end{array}$ & & & & & & & & 2 & & & & \\
\hline
\end{tabular}

Cavalos of the Paranapanema River basin and distributed in 9 families and 27 genera (Tables 3 and 4). The results for taxon richness, diversity indices, dominance and evenness indicated insignificant variation among the lakes. Lake Coqueiral, which is in the Paranapanema River basin and permanently connected to the river, had a greater abundance of coleopterans than Lake Cavalos, which is in the same floodplain but disconnected from the river. Conversely, in the Mogi-Guaçu basin, the results showed a lower abundance of coleopterans in Lake Diogo, connected to the river, than in the disconnected Lake Óleo (Table 5).

The MDS analysis was used to generate Figure 3, where it can be seen that the lakes in the Paranapanema River basin form a cluster, while those related to the Mogi-Guaçu River are far apart, confirming the low similarity between the fauna in Lakes Diogo and Óleo. Axes 1 and 2, used to build this chart, were found to explain $76 \%$ of the data variance. According to the SIMPER analysis, the taxa that 
Table 2. Abundance of Coleoptera coletados in Lake Óleo for each month from March 2010 to February 2011.

\begin{tabular}{|c|c|c|c|c|c|c|c|c|c|c|c|c|}
\hline & \multicolumn{12}{|c|}{ Lake Óleo } \\
\hline & Mar & Apr & May & Jun & Jul & Aug & Sep & Oct & Nov & Dec & Jan & Feb \\
\hline \multicolumn{13}{|l|}{ Curculionidae } \\
\hline $\begin{array}{l}\text { Cyrtobagous singularis Hustache, } \\
1929 \text { A }\end{array}$ & 2 & 2 & & 1 & & 1 & 1 & & 5 & 3 & 6 & \\
\hline $\begin{array}{l}\text { Neochetina eichorniae Warner, } \\
1970 \text { A }\end{array}$ & 1 & & & & 1 & & & & & & & \\
\hline Sibina sp. A & & & & & & & & & 1 & & & \\
\hline Curculionidae L & & & 1 & & & & & & & & 1 & \\
\hline \multicolumn{13}{|l|}{ Dytiscidae } \\
\hline Bidessonotus A & & & & & & & 1 & & & & & \\
\hline Laccophilus A & & & 1 & 3 & & & & & & & & \\
\hline Liodessus A & & & & & & & 1 & & & & & \\
\hline Amarodytes L & & 1 & & & & & & & & & & \\
\hline Hydrovatus L & & & & & & & & & & & 1 & \\
\hline Laccophilus L & 2 & 1 & & & & & & & & & 1 & 6 \\
\hline Vatellus L & & 1 & & & & & & & & & & \\
\hline \multicolumn{13}{|l|}{ Elmidae } \\
\hline Hexacylloepus L & & & & & & 1 & & & & & & \\
\hline \multicolumn{13}{|l|}{ Hydrochidae } \\
\hline Hydrochus A & & & & & 6 & 4 & & 4 & & 1 & & \\
\hline \multicolumn{13}{|l|}{ Hydrophilidae } \\
\hline Derallus A & 21 & 18 & 29 & 31 & 41 & 57 & 81 & 18 & 22 & 27 & 72 & 1 \\
\hline Helochares A & & 2 & & & 10 & 6 & & 1 & 2 & 7 & 2 & 3 \\
\hline Phaenonotum A & & & & & 1 & 2 & 1 & 1 & & & & \\
\hline Tropisternus A & & 1 & 1 & 3 & 13 & 5 & 2 & 1 & 2 & 3 & & 2 \\
\hline Derallus L & 93 & 26 & 53 & 46 & 45 & 91 & 91 & 124 & 135 & 58 & 73 & 36 \\
\hline Enochrus L & & & & & & & & 1 & & & & 1 \\
\hline Helochares L & 3 & 1 & 1 & & & 2 & 8 & 8 & 10 & 30 & 30 & 53 \\
\hline Tropisternus L & 4 & 1 & & & & 1 & 16 & 14 & 5 & 18 & 14 & 12 \\
\hline Lampyridae L & & & & 2 & 1 & 2 & & 1 & 5 & 3 & 4 & \\
\hline \multicolumn{13}{|l|}{ Noteridae } \\
\hline Hydrocanthus A & 14 & 3 & 2 & 22 & 49 & 32 & 22 & 7 & 16 & 7 & & 10 \\
\hline Suphis A & & 1 & & & & & & 1 & 2 & 5 & & 1 \\
\hline Hydrocanthus L & 10 & & & & & 2 & 11 & 49 & 39 & 6 & 6 & 1 \\
\hline Pronoterus/Mesonoterus L & & & & & & & & & 1 & 2 & & \\
\hline Suphis L & & 1 & & & & & & 1 & 8 & 28 & 2 & 4 \\
\hline Scirtidae L & & 2 & 27 & 4 & 22 & 17 & 11 & 52 & & 78 & 34 & 362 \\
\hline
\end{tabular}

L = larva; A = adult; Mar = march; Apr = april; May = may; Jun = june; Jul = july; Aug = august; Sep = september; Oct = october; Nov $=$ november; Dec $=$ december; Jan $=$ january; Feb $=$ february.

contributed most to this dissimilarity were Helochares (larva), Derallus (adult and larva) and Cyrtobagous similaris Hustache, 1929 (adult) (Table 6).

The results of the PERMANOVA analysis showed no difference between the fauna composition in the rainy and dry periods $(p=0.1989)$. This similarity of the fauna between seasons was quite evident and can be seen clearly in Figure 4, which represents the MDS analysis of these data. Axes 1 and 2, used for this chart, explained $68 \%$ of the variance.

\section{Discussion}

The data collected here on the richness and abundance of Coleoptera associated with Salvinia with the literature reports on aquatic coleopterans, in which some authors pick out the family Hydrophilidae as the most abundant 
Table 3. Abundance of Coleoptera coletados in Lake Coqueiral for each month from March 2006 to February 2007.

\begin{tabular}{|c|c|c|c|c|c|c|c|c|c|c|c|c|}
\hline & \multicolumn{12}{|c|}{ Lake Coqueiral } \\
\hline & Mar & Apr & May & Jun & Jul & Aug & Sep & Oct & Nov & Dec & Jan & Feb \\
\hline Crysomelidae A & & & & & & & & 1 & & & & \\
\hline \multicolumn{13}{|l|}{ Curculionidae } \\
\hline Ochetina bruchi Hustache, 1926 A & & & & & & 2 & & & & 2 & 2 & \\
\hline $\begin{array}{l}\text { Neochetina eichorniae Warner, } \\
1970 \text { A }\end{array}$ & & & & & & 2 & & & & 1 & 2 & \\
\hline Curculionidae L & 1 & & & & & & & & & & & \\
\hline \multicolumn{13}{|l|}{ Dytiscidae } \\
\hline Bidessonotus A & & & & & 1 & & 1 & & & & & \\
\hline Laccodytes A & & & & & & 1 & & & & & & \\
\hline Laccophilus A & & & & & & 3 & & & & & & \\
\hline Liodessus A & & & & 1 & 1 & & 1 & & & & & \\
\hline Thermonectus A & & & & & & & & & 1 & & & \\
\hline Celina $\mathrm{L}$ & & & & & & & & & 1 & & & \\
\hline Laccophilus L & & & & & & & & & & & 1 & 1 \\
\hline Morfotipo $1 \mathrm{~L}$ & & & & & & & & & & & & 1 \\
\hline \multicolumn{13}{|l|}{ Hydrochidae } \\
\hline Hydrochus A & & & & & & 23 & 187 & 82 & 3 & 39 & 12 & \\
\hline \multicolumn{13}{|l|}{ Hydrophilidae } \\
\hline Helochares A & & & 7 & 15 & 9 & 9 & 6 & 6 & 9 & 7 & 30 & 3 \\
\hline Phaenonotum A & & 1 & 1 & 1 & & 1 & 4 & & 24 & 4 & 5 & \\
\hline Tropisternus A & & & 7 & 15 & 9 & 12 & 4 & 25 & 3 & 14 & 7 & \\
\hline Enochrus L & & & 1 & & 1 & & & 1 & & & & 3 \\
\hline Helochares L & 6 & 16 & 19 & 32 & 43 & 48 & 8 & 14 & 12 & 6 & 44 & 68 \\
\hline Tropisternus L & & 2 & 2 & 18 & 1 & 15 & & 4 & 13 & 20 & 64 & 58 \\
\hline Lampyridae L & & 4 & & & 1 & 5 & & & & & & 1 \\
\hline \multicolumn{13}{|l|}{ Noteridae } \\
\hline Hydrocanthus A & & 7 & 4 & 3 & 10 & 110 & 25 & 78 & 27 & 158 & 7 & \\
\hline Mesonoterus A & & & & & & & & & 1 & & & \\
\hline Suphis A & & & & & & 9 & 2 & 2 & 7 & 1 & 3 & \\
\hline Suphisellus A & & & 1 & & & & 1 & 1 & 1 & 2 & & 1 \\
\hline Hydrocanthus L & & & 1 & & & 1 & 1 & & 1 & & 3 & 9 \\
\hline Pronoterus/Mesonoterus L & & & & & & & & 1 & 1 & & & 3 \\
\hline Suphis L & 1 & 1 & & & & & & & & & & 2 \\
\hline Scirtidae L & 15 & 109 & 109 & 108 & 115 & 131 & 47 & 65 & 16 & 50 & 50 & 104 \\
\hline \multicolumn{13}{|l|}{ Staphylinidae } \\
\hline Stenus A & & & & & & & 1 & & & & & \\
\hline
\end{tabular}

$\mathrm{L}=$ larva; A = adult; Mar = march; Apr = april; May = may; Jun = june; Jul = july; Aug = august; Sep = september; Oct = october; Nov $=$ november; Dec $=$ december; Jan $=$ january; Feb $=$ february.

in ponds and lakes, followed by Dytiscidae and Scirtidae (Nascimento et al., 2011; Benetti and Hamada, 2003). Boneto et al. (2011) observed that the greatest number of hydrophilids was found in stands of Eichhornia azurea (blue water hyacinth) in Lake Cascalho in the Upper Paraná River basin (MS, Brazil), while Moretti et al. (2003) recorded the largest number of dytiscids on Pontederia lanceolata in Coqueiro Bay, Poconé Swamp (MT, Brazil).

Silva and Henry (2013), in a comparative study of the macroinvertebrate phytofauna associated with Eichhornia azurea in 6 oxbow lakes on the Parapanema River, identified Dytiscidae, Noteridae and Hydrophilidae, at both the larval and adult stage, noterid larvae being the most abundant. Many species in the families Dytiscidae and Noteridae are known to associate with aquatic plants possessing aerenchyma, using them for oviposition and pupation, while those in other families, such as Hydrophilidae and Scirtidae, use aquatic macrophytes possibly as a source of food, given that most of these species are herbivorous (Benetti and Cueto, 2004).

The family Scirtidae was collected only at the larval stage, since the adults are terrestrial and inhabit the riparian zone, flying or walking over stones or in the vegetation (Brown, 1987). Specimens of other families collected, such 
Table 4. Abundance of Coleoptera coletados in Lake Cavalos for each month from March 2006 to February 2007.

\begin{tabular}{|c|c|c|c|c|c|c|c|c|c|c|c|c|}
\hline & \multicolumn{12}{|c|}{ Lake Cavalos } \\
\hline & Mar & Apr & May & Jun & Jul & Aug & Sep & Oct & Nov & Dec & Jan & Feb \\
\hline Crysomelidae A & & & & & & & & & & & 1 & \\
\hline \multicolumn{13}{|l|}{ Curculionidae } \\
\hline Ochetina bruchi Hustache, 1926 A & & & & & & 1 & 1 & & & & & \\
\hline $\begin{array}{l}\text { Neochetina eichorniae Warner, } \\
1970 \text { A }\end{array}$ & & & & 1 & & 6 & 2 & & & & 1 & \\
\hline Curculionidae L & & & & & & 1 & & & & & & \\
\hline \multicolumn{13}{|l|}{ Dytiscidae } \\
\hline Anisomeria A & & & & & & & 1 & & & & & \\
\hline Desmopachria A & & 1 & & & & & & & & & & \\
\hline Hydaticus A & & & & & & & 1 & & & & & \\
\hline Laccophilus A & & & & & 1 & 15 & 26 & & & 3 & & \\
\hline Liodessus A & & & & & & & 1 & & & & & \\
\hline Neobidessus A & & & & & & & 1 & & & & & \\
\hline Megadytes A & & & & 1 & & & & & & & & \\
\hline Thermonectus A & & & & 1 & & & & & & & & \\
\hline Tribo Bidessini A & & & & 3 & & & & & & & & \\
\hline Hydrovatus $\mathrm{L}$ & & & & & & & & & & 1 & & \\
\hline Laccophilus L & 1 & & & & & & & & & & & \\
\hline \multicolumn{13}{|l|}{ Hydrochidae } \\
\hline Hydrochus A variação & & & & & & & & & 1 & & & \\
\hline Hydrochus A & & & & 4 & 14 & 7 & 14 & & 2 & 9 & & \\
\hline \multicolumn{13}{|l|}{ Hydrophilidae } \\
\hline Helochares A & 3 & 7 & 13 & 25 & 11 & 23 & 10 & 24 & 2 & 7 & 11 & 4 \\
\hline Phaenonotum A & & 5 & & 1 & 1 & 6 & 12 & 6 & 2 & 2 & 1 & 1 \\
\hline Tropisternus A & 1 & 3 & 6 & 20 & 9 & 16 & 17 & 52 & 22 & 34 & 1 & 3 \\
\hline Berosus L & & & & & & & & & & 2 & & \\
\hline Enochrus L & & 1 & & & & & & & & 2 & & \\
\hline Helochares L & 28 & 23 & 5 & 17 & 19 & 31 & 15 & 80 & 14 & 19 & 48 & 19 \\
\hline Paracymus L & & & & & & & & 1 & & 1 & & \\
\hline Tropisternus L & 7 & 12 & 9 & 14 & & & & 13 & 29 & 23 & 25 & 11 \\
\hline \multicolumn{13}{|l|}{ Noteridae } \\
\hline Hydrocanthus A & 2 & 13 & 8 & 10 & 26 & 41 & 76 & 101 & 105 & 106 & 9 & 8 \\
\hline Notomicrus A & & & & & & 1 & 1 & & & & & \\
\hline Mesonoterus A & & & & & & 1 & & & & 1 & & \\
\hline Pronoterus A & & & & & & 1 & & & & & & \\
\hline Suphis A & & 1 & & & & & & & 1 & 2 & & \\
\hline Suphisellus A & 1 & & & 6 & & 3 & 10 & & & & 1 & \\
\hline Hydrocanthus L & 3 & 4 & & & & & & & & & 5 & 4 \\
\hline Pronoterus/Mesonoterus L & 2 & & & & & & & & & & & \\
\hline Scirtidae L & 14 & 65 & 13 & 46 & 98 & 81 & 35 & 28 & 5 & 18 & 5 & 25 \\
\hline
\end{tabular}

$\mathrm{L}$ = larva; A = adult; Mar = march; Apr = april; May = may; Jun = june; Jul = july; Aug = august; Sep = september; Oct = october; Nov $=$ november; Dec $=$ december; Jan $=$ january; Feb $=$ february.

as Curculionidae, Chrysomelidodae and Staphylinidae, are not strictly aquatic (Jäch and Balke, 2008; Majka, 2008), but are associated with riparian vegetation and can live on the emergent parts of aquatic plants, especially when they are related to the plants of the terrestrial habitat on the neighboring bank, as is the case at the study sites. The majority of the species in the family Lampyridae are land-based, with very few aquatic representatives at the larval stage (Jäch and Balke, 2008).

According to Santos and Thomaz (2004) and Takeda et al. (2004), flood pulse events and the degree of connectivity between floodplain lakes and the river are factors that strongly influence the structure of the aquatic plants in those lakes and, consequently, the associated 
Table 5. Observed metrics for each lake under study (M: mean. SD: standard deviation).

\begin{tabular}{|c|c|c|c|c|c|c|c|c|}
\hline & M & SD & $\mathbf{M}$ & SD & $\mathbf{M}$ & SD & $\mathbf{M}$ & SD \\
\hline & Diogo & Diogo & Óleo & Óleo & Coqueiral & Coqueiral & Cavalos & Cavalos \\
\hline $\mathrm{S}$ & 12.75 & 2.56 & 12.08 & 2.64 & 10.91 & 3.28 & 10.91 & 3.23 \\
\hline $\mathrm{N}$ & 174.33 & 70 & 220.5 & 111.74 & 212.25 & 95.49 & 161.41 & 78.48 \\
\hline $\mathrm{D}$ & 0.24 & 0.08 & 0.29 & 0.1 & 0.35 & 0.15 & 0.24 & 0.06 \\
\hline $\mathrm{H}^{\prime}$ & 1.79 & 0.27 & 1.59 & 0.29 & 1.43 & 0.41 & 1.73 & 0.21 \\
\hline E & 0.7 & 0.06 & 0.64 & 0.1 & 0.6 & 0.11 & 0.74 & 0.09 \\
\hline
\end{tabular}

$\mathrm{S}=$ taxon richness observed; $\mathrm{N}=$ total abundance; $\mathrm{S}=$ Simpson's dominance; H' = Shannon's diversity; $\mathrm{E}=$ Pielou's evenness.

Table 6. Taxa that contributed the most to the dissimilarity between Lakes Diogo and Óleo according to the SIMPER analysis.

\begin{tabular}{lccc}
\hline \multicolumn{1}{c}{ Taxa } & Cumul. Cont. \% & Mean abund. 1 & Mean abund. 2 \\
\hline Helochares L & 11.25 & 1.75 & 0.68 \\
Derallus A & 22.15 & 0.39 & 1.39 \\
Derallus L & 32.22 & 0.84 & 1.81 \\
Cyrtobagous singularis Hustache. 1929 A & 41.25 & 1.14 & 0.21 \\
Helochares A & 49.88 & 1.21 & 0.33 \\
Hydrocanthus A & 58.28 & 0.16 & 0.97 \\
Scirtidae L & 65.08 & 1.25 & 1.14 \\
Tropisternus L & 70.78 & 0.6 & 0.59 \\
\hline
\end{tabular}

Cumul. Cont. $=$ cumulative contribution; Abund. $=$ abundance; $\mathrm{L}=$ larva; $\mathrm{A}=$ adult.

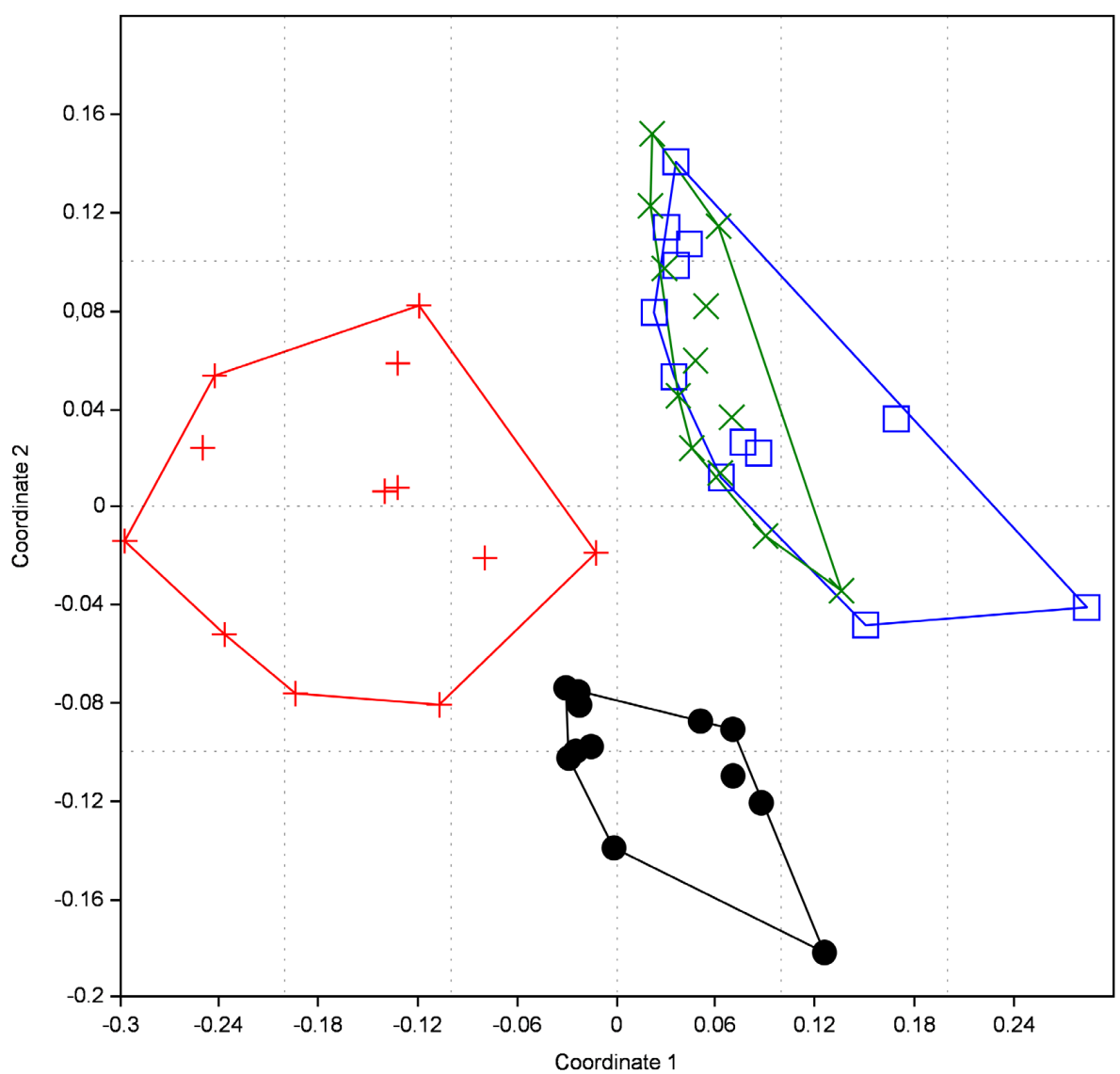

Figure 3. Chart showing MDS analysis based on Bray-Curtis dissimilarity of Coleoptera abundance data for the organisms in each collection made in the 4 lakes: + Lake Óleo, •: Lake Diogo, $\square$ : Lake Coqueiral and x: Lake Cavalos. 


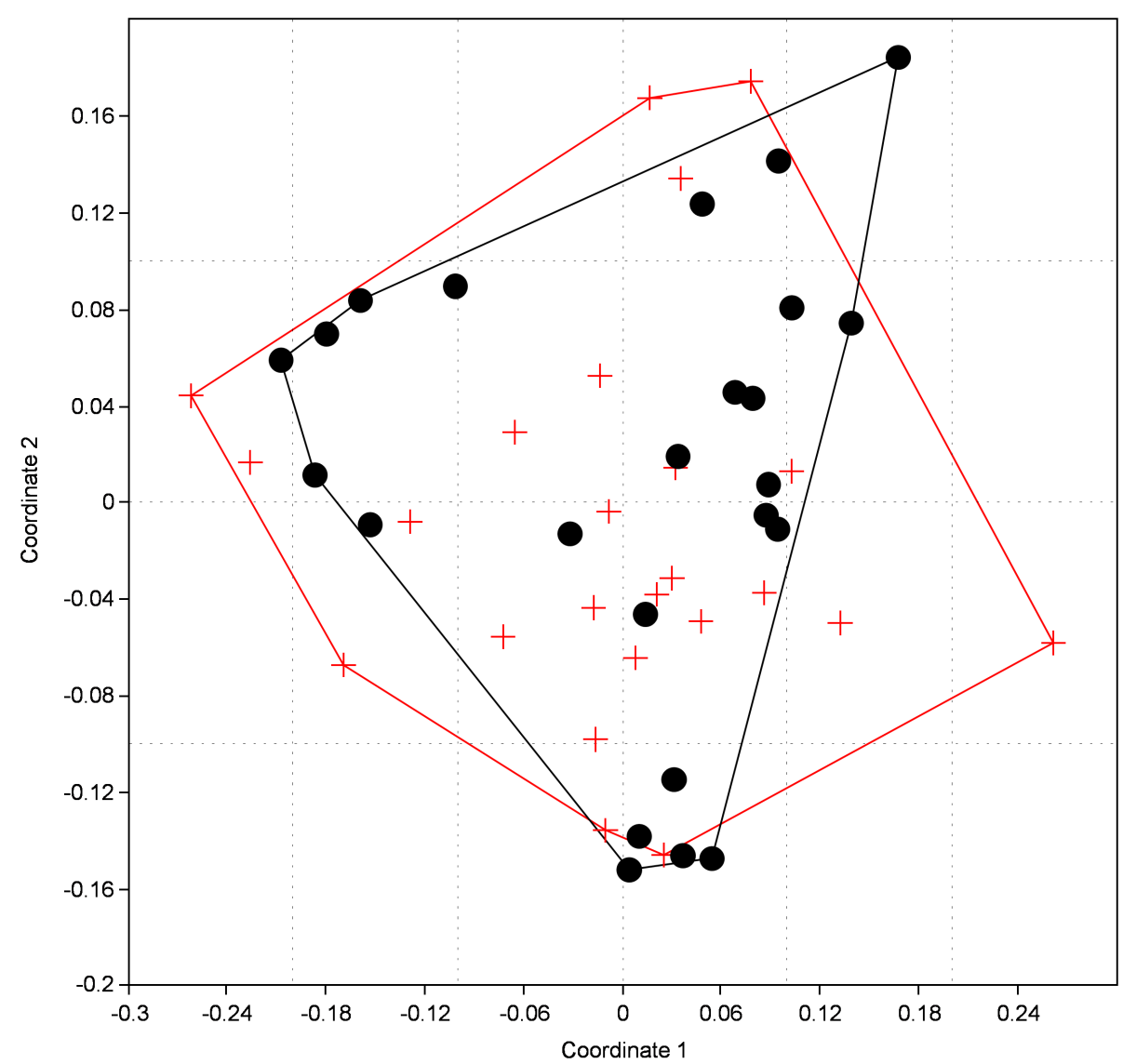

Figure 4. Chart showing MDS analysis based on Bray-Curtis dissimilarity of Coleoptera abundance data for the organisms in collections made in the rainy and dry seasons: + rainy, $\bullet$ : dry.

fauna. Albertoni et al. $(2005,2007)$ noted that Salvinia is a common macrophyte in subtropical aquatic systems that forms dense stands all year round. Such perennial plants, when they also cover a broad area (owing to an extended root system), exhibit high richness, abundance and diversity of Coleoptera (Scheffer, 1998; Thomaz and Cunha, 2010).

In the lakes under study, Salvinia formed a dense vegetation cover, which favored the high taxon richness observed among the Coleoptera, also observed by Valladares et al. (2002) in shallow lakes located at one end of the Castille Canal, north of the Meseta Ibérica. Fontanarrosa et al. (2013) also reported a dominance of those coleopterans associated with macrophytes, in two lakes in the province of Buenos Aires, Argentina.

Studies of other groups of invertebrates associated with Salvinia have shown similar patterns. In Lake Coqueiral, Davanso (2010) observed very high densities of chironomid larvae and oligochaetes and, to explain these data, emphasized the importance of the permanent connection between this lake and the river. Low connectivity hinders the exchange of matter, energy and organisms and thus reduces biodiversity (Ward et al., 1999). Conversely, as connectivity rises between a floodplain lake and the river, organisms acquire a new way to migrate between the two habitats and the joint channel begins to function as a "dispersion corridor" for populations of aquatic organisms (Gubiani, 2009). This may have been a reason for the similarity between the lakes in the same drainage basin.

According to the PERMANOVA and MDS analyses, there was no significant difference in fauna between the rainy and dry periods, suggesting that the seasonal fluctuation in water level does not interfere with the composition of the aquatic coleopteran fauna. This is in contradiction with a report by Silva and Henry (2013) that the richness and abundance of macroinvertebrates associated with Eichhornia azurea were greater in the period when the river-lake connectivity was higher; they explained this in terms of the probable influence of the flood pulse, which would favor greater heterogeneity of habitats for the community.

Fulan et al. (2011) recorded that Lake Cavalos, despite being small and isolated, has a considerable density of fish, which can prey on Odonata larvae. This predation could equally apply to coleopterans; indeed, in this lake, a smaller number of specimens were collected than in the other lakes in this study. Ferreira (1998) and Meschiatti (1995) noted the presence of insect larvae in the stomach contents of herbivore/insectivore species of fish, in Lakes Óleo and Diogo, respectively. The invertebrates 
associated with aquatic macrophytes are important natural food sources for fish and other higher-level consumers (Ohtaka et al., 2011). The beetle larva is the stage most vulnerable to predation, as it has not yet developed the very hard exoskeleton possessed by the adult (Bosi, 2001).

The MDS analysis of the four lakes showed that there is little similarity between the coleopteran communities of Lakes Diogo and Óleo. This is probably due to the different species of Salvinia found in the macrophyte stands in the two lakes. In Lake Diogo, these stands consist mainly of $S$. auriculata Aublet, which has longer and denser roots than the species observed in Lake Óleo, S. molesta Mitchell. The latter was reported by Nelson (2009) to have false roots, thinner and more delicate than those of $S$. auriculata. This difference could well explain the greater abundance of the genus Derallus (Hydrophilidae) in Lake Óleo, both at the larval and adult stages. Beetles in this genus are characteristically small $(<3.0 \mathrm{~mm})$, enabling them to inhabit the finer roots of $S$. molesta more successfully than larger organisms.

Based on the analyzes of this study it is concluded that there is greater similarity between the communities of Coleoptera the lakes that are inserted in the same region and that, in this study, the connectivity between river and lake is not decisive for the richness and abundance of aquatic fauna of Coleoptera. And the richness and abundance of aquatic Coleoptera associated range with the species of Salvinia.

\section{Acknowledgements}

We are grateful to CNPq for the scholarship; to Dr Rosemary Davanso; Dr João Fulan and Prof. Dr Raoul Henry for donating material from the oxbow lakes in the Paranapanema River basin; to Dr Sérgio Vanin and Angélico Vasenjo for their help in the identification of Curculionidae and Staphylinidae and to all those who made it possible to carry out this study.

\section{References}

AFONSO, A.A.O., 2002. Relações da fauna associada à Eichhornia azurea (Swartz) Kunth com as variáveis abióticas em lagoas laterais de diferentes graus de conexão ao Rio Paranapanema (zona de desembocadura na Represa de Jurumirim, SP). Botucatu: Universidade Estadual Paulista, 99 p. PhD Thesis in Biological Sciences

ALBERTONI, E.F., PALMA-SILVA, C. and VEIGA, C.C., 2005. Estrutura da comunidade de macroinvertebrados associada às macrófitas aquáticas Nymphoides indica e Azolla filliculoides em dois lagos subtropicais (Rio Grande, RS, Brasil). Acta Biologica Leopoldensia, vol. 27, no. 3, pp. 137-145.

ALBERTONI, E.F., PRELLVITZ, L.J. and PALMA-SILVA, C., 2007. Macroinvertebrates fauna associated with Pistia stratiotes e Nymphoides indica in subtropical lakes (south Brazil). Revista Brasileira de Biologia $=$ Brazilian Journal of Biology $=$ Revista Brasileira de Biologia, vol. 67, no. 3, pp. 499-507. http://dx.doi. org/10.1590/S1519-69842007000300015.
ANDERSON, M.J., 2001. A new method for non-parametric multivariate analysis of variance. Austral Ecology, vol. 26, no. 1, pp. 32-46.

ARCHANGELSKY, M., MANZO, V., MICHAT, M.C. and TORRES, P.L.M., 2009. Coleoptera. In: E. DOMINGUEZ and H.R. FERNÁNDEZ, eds. Macroinvertebrados bentónicos sudamericanos. Sistemática y biología. Tucumán: Fundación Miguel Lillo, pp. 411-468.

BENETTI, C.J., CUETO, J.A.R. and FIORENTIN, G.L., 2003 [viewed 29 November 2012]. Gêneros de Hydradephaga (Coleoptera: Dytiscidae, Gyrinidae, Haliplidae, Noteridae) citados para o Brasil, com chaves de identificação. Biota Neotropica [online], vol. 3, no. 1. Available from: http://www.biotaneotropica.org.br/v3n1/ pt/abstract?identification-key+BN00803012003.

BENETTI, C.J. and CUETO, J.A., 2004. Fauna composition of water beetles (Coleoptera: Adephaga) in seven water environments in the municipality of Gramado, RS, Brazil. Acta Limnologica Brasiliensia, vol. 16, no. 1, pp. 1-11.

BENETTI, C.J., CUETO, J.A.R. and FIORENTIN, G.L., 2006. Chaves de identificação para famílias de coleópteros aquáticos ocorrentes no Rio Grande do Sul, Brasil. Neotropical Biology and Conservation, vol. 1, no. 1, pp. 24-28.

BENETTI, C.J. and HAMADA, N., 2003. Fauna de coleópteros aquáticos (Insecta: Coleoptera) na Amazônia Central, Brasil. Acta Amazonica, vol. 33, no. 3, pp. 1-10.

BONETO, D.D., BATISTA-SILVA, V.F. and BAILLY, D., 2011. Coleópteros associados à Eichhornia azurea na Lagoa do Cascalho: composição, abundância e influência de fatores limnológicos. Anais do Encontro de Iniciação Científica-ENIC, no. 3 .

BOSI, G., 2001. Abundance, diversity and seasonal succession of dytiscid and noterid beetles (Coleoptera: Adephaga) in two marshes of the Eastern PoPlain (Italy). Hydrobiologia, vol. 459, no. 1-3, pp. 1-7. http://dx.doi.org/10.1023/A:1012594615880.

BROWN, H.P., 1987. Biology of riffle beetles. Annual Review of Entomology, vol. 32, no. 1, pp. 253-273. http://dx.doi.org/10.1146/ annurev.en.32.010187.001345.

CAVALHEIRO, F., BALLESTE, M.V.R. and SANTOS, J.E., 1990. Propostas preliminares referentes ao plano de zoneamento e manejo da Estação Ecológica de Jataí. Acta Limnologica Brasiliensia, vol. 3, no. 2, pp. 951-968.

DAVANSO, R.C.S. and HENRY, R., 2006. A biodiversidade bentônica em lagoa marginal ao rio Paranapanema na zona de sua desembocadura, na represa de Jurumirim. Acta Scientiarum Biologial Sciences, vol. 28, no. 4, pp. 347-357.

DAVANSO, R.C.S., 2010. Composição e abundância de larvas de Chironomidae (Insecta, Diptera) associadas ao sedimento e à macrófita aquática (Salvinia auriculata) em dois rios e em duas lagoas marginais, com e sem conexão com o curso de água. Botucatu: Universidade Estadual Paulista, 112 p. PhD Thesis in Biological Sciences.

EPLER, J.H., 1996. Dentification manual for the water beetles of Florida. Tallahassee: State of Florida Department of Environmental Protection, Division of Water Facilities.

FAIRCHILD, G.W., FAULDS, A.M. and MATTA, J.F., 2000. Beetle assemblages in ponds: effects of habitat e site age. Freshwater Biology, vol. 44, no. 3, pp. 523-534. http://dx.doi. org/10.1046/j.1365-2427.2000.00601.x.

FERREIRA, A.G., 1998. Caracterização de lagoas marginais do rio Mogi-Guaçu na Estação Ecológica de Jatai: composição 
quantitativa da ictiofauna. São Carlos: Universidade Federal de São Carlos, 235 p. PhD Thesis in Science.

FERREIRA-JUNIOR, N. and MENDONÇA, E.C., DORVILLÉ, L.F.M. and RIBEIRO, J.R.I., 1998. Levantamento preliminar e distribuição de besouros aquáticos (Coleoptera) na restinga de Marica, RJ. In: J.L. NESSIMIAN and A.L. CARVALHO, eds. Ecologia de insetos aquáticos. Rio de Janeiro: PPGE-UFRJ, pp. 129-140. Série Oecologia Brasiliensis, no. 5.

FERREIRA-JUNIOR, N., NICOLINI, L.B. and NESSIMIAN, J.L., 2006. Description of the third instar larvae of Megadytes latus (Fabricius) (Coleoptera, Dytiscidae), with an identification key for described larvae of the genus. Revista Brasileira de Zoologia, vol. 23, no. 3, pp. 792-795. http://dx.doi.org/10.1590/ S0101-81752006000300025.

FERREIRA-JUNIOR, N. and BRAGA, R.B., 2009. Dytiscidae e Noteridae (Insecta: Coleoptera) recorded from Rio de Janeiro State, Brazil. Arquivos do Museu Nacional, vol. 67, no. 3-4, pp. 321-327.

FONTANARROSA, M.S., CHAPARRO, G.N. and O'FARRELL, I., 2013. Temporal and spatial patterns of macroinvertebrates associated with small and medium-sized free-floating plants. Wetlands, vol. 33, no. 1, pp. 47-63. http://dx.doi.org/10.1007/ s13157-012-0351-3.

FULAN, J.A., HENRY, R. and DAVANSO, R.C.S., 2011. Effects of daily changes in environmental factors on the abundance and richness of Odonata. Acta Limnologica Brasiliensia, vol. 23, no. 1, pp. 23-29. http://dx.doi.org/10.4322/actalb.2011.015.

GLOWACKA, I., SOSZKA, G.J. and SOSZKA, H., 1976. Invertebrates associated with macrophytes. In: E. PIECZYNSKA, ed. Selected problems of lake littoral ecology. Warszawa: Wydawnictwa Uniwersytetu Warszawskiego. 238 p.

GUBIANI, E.A., 2009. Abordagem metapopulacional: uma ferramenta para a biologia da conservação. In: F.A. LANSACTÔHA, E. BENEDITO and E.F. OLIVEIRA, orgs. Contribuições da história da ciência e das teorias ecológicas para a limnologia. Maringá: EDUEM, pp. 277-302.

HAMMER, Ø., HARPER, D.A.T. and RYAN, P.D., 2001. PAST: Paleontological Statistics software package for education and data analysis. Palaeontologia Eletronica, vol. 4, no. 1, pp. 1-9.

HENRY, R., 2003. Os ecótonos nas interfaces dos ecossistemas aquáticos: conceitos, tipos, processos e importância. Estudo de aplicação em lagoas marginais ao Rio Paranapanema na zona de sua desembocadura na Represa de Jurumirim. In: R. HENRY, org. Ecótonos nas interfaces dos ecossistemas aquáticos. São Carlos: RIMA Editora, pp. 1-28.

JÄCH, M.A. and BALKE, M., 2008. Global diversity of water beetles (Coleoptera) in freshwater. Hydrobiologia, vol. 595, pp. 419-442.

MAJKA, C.G., 2008. The aquatic Coleoptera of Prince Edward Isle, Canada: new records and faunal composition. Zookeys, vol. 2, no. 1, pp. 239-260.

MARÇAL-SIMABUKU, M.A. and PERET, A.C., 2002. Alimentação de peixes (Osteichthyes, Characiformes) em duas lagoas de uma planície de inundação brasileira da bacia do rio Paraná. Interciencia, vol. 27 , no. 6 , pp. 299-305.

MERRITT, R.W. and CUMMINS, K.W., 1996. An introductionto the aquatic insects of North America. Iowa: Kendall/Hunt Publishing Company. 862 p.

MESCHIATTI, A.J., 1995. Alimentação da comunidade de peixes de uma lagoa marginal do Rio Mogi-Guaçú, SP. Acta Limnologica Brasiliensia, vol. 7, pp. 115-137.
MORETTI, M.S., GOULART, M.D.C. and CALLISTO, M., 2003. Avaliação rápida da macrofauna associada a Eichhornia azurea (Swartz) Kunth, 1843 e Pontederia lanceolata Nutt., 1818 (Pontederiaceae) na Baía do Coqueiro, Pantanal de Poconé (MT/ Brasil). Revista Brasileira de Zoociências, vol. 5, no. 1, pp. 7-21.

NASCIMENTO, L.V., ALBERTONI, E.F. and SILVA, C.P., 2011. Fauna de coleoptera associada à macrófitas aquáticas em ambientes rasos do sul do Brasil. Perspectiva, vol. 35, no. 129, pp. 53-64.

NELSON, L.S., 2009. Giant and common salvinia. In: L.A. GETTYS, W.T. HALLER and M. BELLAUD, eds. Biology and control of aquatic plants. Gainesville: Cover photograph courtesy of SePRO Corporation.

OHTAKA, A., NARITA, T., KAMIYA, T., KATAKURA, H., ARAKI, Y., IM, S., CHHAY, R. and TSUKAWAKI, S., 2011. Composition of aquatic invertebrates associated with macrophytes in Lake Tonle Sap, Cambodia. Limnology, vol. 12, no. 12, pp. 137-144. http://dx.doi.org/10.1007/s10201-010-0330-4.

SANTOS, J.E. and MOZETO, A.A., 1992. Programa de análise de Ecossistemas e Monitoramento Ambiental: Estação Ecológica de Jatai (Luiz Antônio). Ecologia de Áreas Alagaveis da Planície de Inundação do rio Mogi-Guaçu. Projeto Jataí. São Carlos: PPGERN/UFSCar. 59 p. Technical report.

SANTOS, A.M. and THOMAZ, S.M., 2004. The role of connectivity in structuring aquatic macrophytes assemblages. In: A.A. AGOSTINHO, L. RODRIGUES, L.C. GOMES, S.M. THOMAZ and L.E. MIRANDA, eds. Strucrute and functioning of the Paraná river and its floodplain. Maringá: EDUEM, pp. 227-232.

SCHEFFER, M., 1998. Ecology of shallow lakes. London: Chapman \& Hall.

SETZER, J., 1966. Atlas climatológico do Estado de São Paulo. São Paulo: Comissão Interestadual da Bacia do Paraná-Uruguai/Asp.

SILVA, C.V. and HENRY, R., 2013. Aquatic macroinvertebrates associated with Eichhornia azurea (Swartz) Kunth and relationships with abiotic factors in marginal lentic ecosystems (São Paulo, Brazil). Brazilian Journal of Biology = Revista Brasileira de Biologia, vol. 73, no. 1, pp. 149-162. http://dx.doi.org/10.1590/ S1519-69842013000100016.

TAKEDA, A.M., KOBAYASHI, J.T., RESENDE, D.L.M.C., FUJITA, D.S., AVELINO, G.S., FUJITA, R.H., PAVAN, C.B. and BUTAKKA, C.M.M., 2004. Influence of decreased water level on the Chironomidae community of the Upper Paraná River alluvial plain. In: A.A. AGOSTINHO, L. RODRIGUES, L.C. GOMES, S.M. THOMAZ and L.E. MIRANDA, eds. Structure and functioning of the Paraná river and its floodplain. Maringá: EDUEM, pp. 101-106.

THOMAZ, S.M. and CUNHA, E.R., 2010. The role of macrophytes inhabitat structuring in aquatic ecosystems: methods of measurement, causes and consequences on animal assemblages composition and biodiversity. Acta Limnologica Brasiliensia, vol. 22, no. 2, pp. 218-236. http://dx.doi.org/10.4322/actalb.02202011.

VALLADARES, L.F., GARRIDO, J. and GARCIA-CRIADO, F., 2002. The assemblages of aquatic Coleoptera from shallow lakes in the northern Iberian Meseta: influence in environmental Variables. European Journal of Entomology, vol. 99, no. 3, pp. 289-298. http://dx.doi.org/10.14411/eje.2002.040.

WARD, J.V., TOCKNER, K. and SCHIEMER, F., 1999. Biodiversity of floodplain ecosystems: ecotones and connectivity. Regulated Rivers: Research and Management, vol. 15, no. 1-3, pp. 125-139. http:// dx.doi.org/10.1002/(SICI)1099-1646(199901/06)15:1/3<125::AIDRRR523>3.0.CO;2-E. 